\title{
DETECTION OF LEAD FROM SAMPLES OF OCIMUM SANCTUM FROM INDUSTRIAL AREAS OF SURAT CITY-INDIA
}

\author{
${ }^{1}$ Tank Dharti S. \\ ${ }^{2}$ Tank S.K. \\ ${ }^{1}$ Bhagwan Mahavir College of Pharmacy, Surat, India \\ ${ }^{2}$ Department of Biosciences, V.N.S.G.University, Surat, India
}

\begin{abstract}
The taxon Ocimum sanctum is selected because it has versatile role in traditional Indian medicine. Samples of plants (about 10) were collected from the areas where higher amount of heavy metal lead gets accumulated within the soil. After collection of fresh plants they were brought to the laboratory, washed thoroughly and leaves were analyzed for the absorption of lead by plants using AASM. It was surprising that a high amount of lead was found in Ocimum sanctum growing in industrial area. More than 10 samples were analyzed from each sampling station. The maximum lead was detected up to $0.3 \mathrm{mg} / \mathrm{g}$ and the minimum was $0.1 \mathrm{mg} / \mathrm{g}$. Average lead content was reported to be $0.2 \mathrm{mg} / \mathrm{g}$. Ocimum is very widely consumed by the people as common medicine for cold, cough, flu, diabetes, gastric disorders, malaria, arthritis and various skin diseases. Ocimum with high amount of lead $(\mathrm{Pb})$ content leads to chronic health problems like hearing impairments, memory loss, nephrotoxicity, hepatotoxicity and cancer. Ocimum sanctums with accumulated lead antagonize their original purpose to cure disease when consumed.
\end{abstract}

\section{KEYWORDS}

Ocimum sanctum, Lead (Pb), Holy Basil, Medicinal plants, Tulsi.

\section{INTRODUCTION}

Over past few decades, the disposal of various hazardous chemicals, due to rapid urbanization and industrialization has caused marked increase in environmental pollution. Among them heavy metals play a major role in causing several serious health problems to mankind. Compared to organic waste, inorganic waste like heavy metals from various industries, pose a great threat as they cannot be completely eliminated from the ecosystem [1]. The use of herbal medicines is increasing alarmingly in both developing and developed countries due to their reasonable price and above all due to the assumption that natural products are safe [2]. Therefore, medicinal plants and herbal products play a vital role in health care sector of developing nations for the management of diseases.

Lead is one of the heavy metals which have no known biological function and is most widely encountered heavy metal in environmental pollution. Pollution of atmosphere 
and soil with lead from polluted irrigation water, automobile and industrial exhausts, mining and smelting of metalliferous ores, pesticides, utilization of Lead based paints, fertilizers play an important role in contamination of medicinal plants $[2,3,4]$. This Lead enters the plant cells from air, soil and water during growth of plant. By accumulating Lead in above ground tissues and roots, plants can transfer these heavy metal pollutants from soil and atmosphere to food chain and this imposes a serious problem as it is phototoxic to plants as well as exhibit potential harmful effects on animals and humans [5].

Ocimum sanctum Linn. Commonly known as Holybasil, or Tulsi is a well known medicinal plant that has versatile role in traditional medicine [6]. Ocimum sanctum belongs to genus Ocimum comprising of 35 species and family Labitae. These are found in tropical and subtropical regions. They are rich in essential oil and volatile oil [7].

The sacred basil Tulsi is renowned for its religious and spiritual sanctity, as well as for its important role in the traditional Ayurvedic and Unani systems of holistic health and herbal medicine of the East. In Ayurveda, Holybasil is revered as "The Elixir of Life" owing to its wide adaptogenic property and healing power [8].

Ocimum sanctum is also renowned as Holy power plant attributing to its wide medicinal properties such as wound healing, Analgesic, Antihelminthic, Anti-inflammatory, Antibacterial, Antidiabetic, Antioxidant, Immunomodulatory, Antistress, Antiulcerogenic, Lowers dangerous cholesterol and stress related high blood pressure, protects the heart and blood vessels, and has mild blood thinning qualities, thereby decreasing the likelihood of strokes.[7,8,10]. Tulsi is commonly used to treat coughs, colds and flu, head and ear aches, rheumatism and arthritis, malaria, fever, allergies, and various skin diseases, to reduce the toxicity of various poisons, including insect and reptile bites, to expel intestinal parasites, repel insects and purify the air [8].

The aim of present study was to determine Lead contamination in Holybasil plants growing in industrial areas of Surat City. Ocimum with high amount of lead $\left(\mathrm{Pb}^{++}\right)$ content leads to chronic health problems like hearing impairments, memory loss [11], nephrotoxicity [12], High blood pressure, hepatotoxicity and cancer. Holybasil (Tulsi) with accumulated lead antagonize their original purpose to cure disease when consumed.

\section{SAMPLE COLLECTION AND PREPARATION:}

\subsection{Samples:}

Ocimum sanctum. L. is a bushy perennial shrub reaching to a height of $0.5-1.5 \mathrm{~m}$ with simple opposite green leaves petolate and ovate green or purple leaves are $2-4 \mathrm{~cm}$ in length $[9,10]$. Green leaves are selected as samples. 


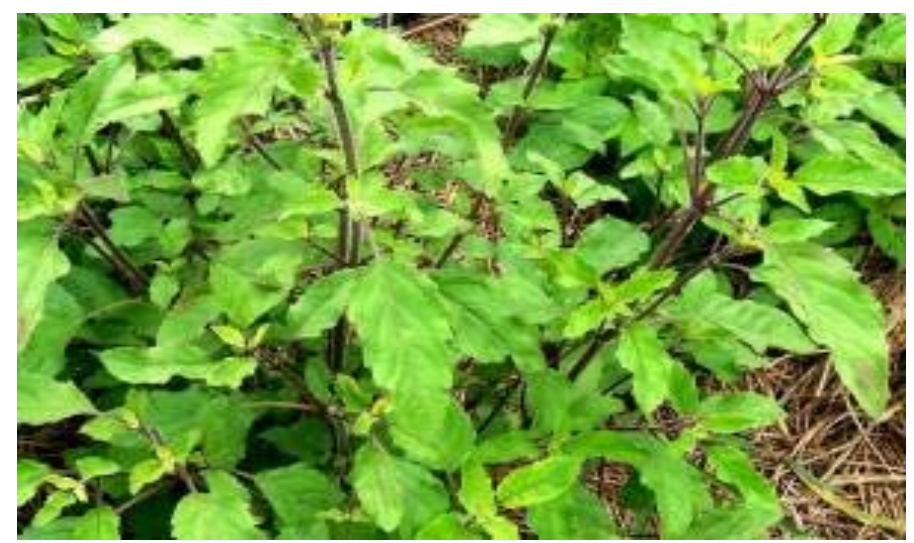

Figure 1: Ocimum sanctum plant

Holy basil leaves were selected as samples owing to their wide medicinal use amongst other parts of the plant. All plant samples were collected in two different sampling stations, both of which are designated as industrial zones namely Hazira and Sachin (See Figure 2). About 10 plant samples were collected from each sampling station at different sites lying within a radius of $1 \mathrm{~km}$ in each station.

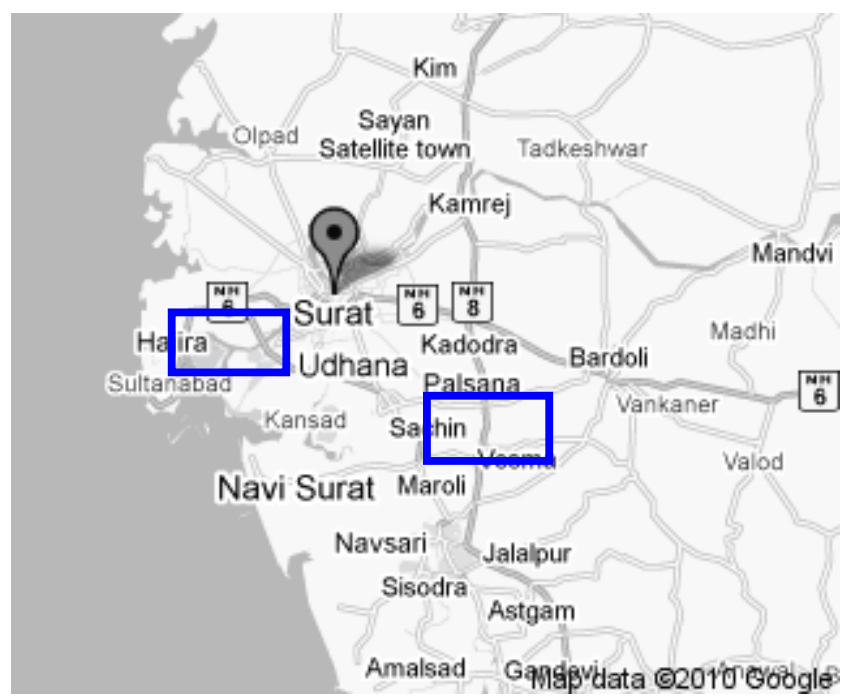

Figure 2: Sampling stations, Hazira and Sachin- industrial areas of Surat city 
After collection of fresh plant leaves, they were brought to the laboratory, washed thoroughly and treated further for their analysis through AAS.

\section{MATERIALS AND METHODS:}

All plant samples were oven dried at $80^{\circ} \mathrm{C}$ for $24 \mathrm{~h}$. To ensure uniform distribution of metals in the sample, the material was milled in a micro hammer cutter and sieved through $1.5 \mathrm{~mm}$ sieve. After homogenization, plant samples were placed in clear paper bags. About $2 \mathrm{~g}$ of dried plant samples was weighted and left in a mixed solution of nitric and hydrochloric acids $(4 \mathrm{HNO} 3: 1 \mathrm{HCl})$ for seven days in closed PTFE vessels. After that samples were digested for two hours in $200^{\circ} \mathrm{C}$, until wet salts were reached. Samples were sent to volume with distilled water and analyzed by AAS method $[14,15]$.

\section{RESULT AND DISCUSSION:}

In table 1 the results of the Lead $\left(\mathrm{Pb}^{++}\right)$concentration $(\mathrm{mg} / \mathrm{g})$ in plant leaf samples collected from different industrial areas of Surat city are implied.

The concentration of Lead $\left(\mathrm{Pb}^{++}\right)$accumulated in leaves of Ocimum sanctum varied in both different sampling stations. The maximum lead concentration that was accumulated in samples collected from Hazira industrial area (sampling station1) was detected to be $0.3 \mathrm{mg} / \mathrm{g}$. (See Table 1). The minimum lead concentration that was accumulated in samples collected from Hazira industrial area (sampling station1) was detected to be $0.18 \mathrm{mg} / \mathrm{g}$. The average lead content reported in collected from Hazira industrial area (sampling station 1 ) was $0.23 \mathrm{mg} / \mathrm{g}$.

Table 1: Lead content in Ocimum sanctum samples collected from different industrial areas of Surat city $(\mathrm{mg} / \mathrm{g})$

\begin{tabular}{|ccc|}
\hline $\begin{array}{c}\text { Sampling } \\
\text { Site }\end{array}$ & $\begin{array}{c}\text { Concentration of Lead in } \\
\text { collected samples (mg/g) } \\
\text { From Sampling Station 1 (Hazira) }\end{array}$ & $\begin{array}{c}\text { Concentration of Lead in collected } \\
\text { samples (mg) }\end{array}$ \\
\hline 1 & 0.21 & 0.15 \\
\hline 2 & 0.18 & 0.21 \\
\hline 3 & 0.23 & 0.12 \\
\hline 4 & 0.20 & 0.10 \\
\hline 5 & 0.27 & 0.19 \\
\hline 6 & 0.24 & 0.20 \\
\hline 7 & 0.30 & 0.14 \\
\hline
\end{tabular}




\begin{tabular}{|lcc|}
\hline 8 & 0.25 & 0.18 \\
\hline 9 & 0.23 & 0.21 \\
\hline 10 & 0.21 & 0.11 \\
\hline
\end{tabular}

The maximum lead concentration that was accumulated in samples collected from Sachin industrial area (sampling station2) was detected to be $0.21 \mathrm{mg} / \mathrm{g}$. The minimum lead concentration that was accumulated in samples collected from Sachin industrial area (sampling station2) was detected to be $0.10 \mathrm{mg} / \mathrm{g}$. The average lead content reported in collected from Hazira industrial area (sampling station 1 ) was $0.23 \mathrm{mg} / \mathrm{g}$. The average lead content reported in collected from Sachin industrial area (sampling station2) was $0.15 \mathrm{mg} / \mathrm{g}$. The maximum lead content in samples collected from both industrial areas was reported to be $0.3 \mathrm{mg} / \mathrm{g}$. The minimum lead content in samples collected from both industrial areas was reported to be $0.1 \mathrm{mg} / \mathrm{g}$. Average lead content in samples collected from both industrial areas was reported to be $0.2 \mathrm{mg} / \mathrm{g}$.

Compared to samples collected from Hazira industrial area, the lead content in samples from Sachin industrial area was found to be less.

The WHO permissible level for $\mathrm{Pb}^{++}$is $10 \mathrm{mg} / \mathrm{kg}$ (WHO 1998). All analyzed samples in present study have Lead content above $10 \mathrm{mg} / \mathrm{kg}$. Thus, they contained very high levels of Lead $\left(\mathrm{Pb}^{++}\right)$and hence may have adverse effects normally associated with Lead toxicity on people who patronize these herbs for their health needs. Ocimum sanctum with accumulated lead antagonizes their original purpose to cure disease when consumed.

\section{CONCLUSION}

Though use of herbal medicines and herbal products is increasing dramatically worldwide, environmental pollution especially with heavy metals imposes serious problems on quality of medicinal plants and henceforth their products. Thus, it is concluded that medicinal plants or plant parts used for different types of disease treatment and as a raw material for various herbal formulations should be evaluated for heavy metal contamination to serve their medicinal purpose of curing the disease in humans beings.

\section{ACKNOWLEDGEMENTS:}

The authors are grateful to their respective institutions for their kind help and encouragements during the study.

\section{REFERENCES:}


[1] Babu, K., Maheshwari, U., 2006. In vivo studies on the effect of Ocimum sanctum L. leaf extract in modifying the genotoxicity induced by chromium and mercury in Allium root meristems. Journal of Environmental Biology, 27(1), 9395.

[2] Henok, B., Hymete, A., 2010. Lead and Cadmium accumulation in Medicinal Plants collected from environmentally different sites. Bulletin of Environmental contamination and Toxicology 84(2), 197-201.

[3] Pendias, A., Pendias, H., 2000. Trace Elements in Soils and Plants. CRC Press, Boca Raton, USA.

[4] Harrison, R. M., Laxen, D. H., 1981. Lead Pollution, Causes and Control: Introduction. Chapman and Hall, Inc., New York, USA.

[5] Hussain, I., Khan, F., Khan, I., Khan, L., Ullah, W., 2006. Determination of Heavy Metals in Medicinal Plants. Jour. Chem.Soc.Pak 28(4), 347-351.

[6] Gupta, S., Srivastava, J., Srivastava, S., 2002. Validation of traditional claim of Tulsi, Ocimum sanctum L. as a medicinal plant. Indian Journal of Experimental Biology, 40, 765-773.

[7] Pattanayak, P., Behera, P., Das, D., Panda, S.K., 2010. Ocimum sanctum Linn: A reservoir Plant for therapeutic applications. Pharmacognosy Reviews, 4 (7), 95-105.

[8] Miller, R., Miller, S., 2003. Tulsi Queen of Herbs: India's Holy Basil, The Green Isle Enterprise, Salt Spring Island, BC.

[9] Das, S.K., Vasudevan, D.M., 2006. Tulsi: The Indian holy power plant. Natural Product Radiance, 5 (4), 279-283.

[10] Rastogi, R.P., Mehrotra, B.N., 1995. Ocimum sanctum In: Compendium of Indian Medicinal Plants. Publication and Information Directorate, CSIR, New Delhi, 4 (510).

[11] Pearce, J. M. S., 2007. Burton's line in lead poisoning. European neurology, 57(2), 118-119.

[12] Ekong, E., Jaar, B., Weaver, V., 2006. Lead-related nephrotoxicity: a review of the epidemiologic evidence. Kidney international, 70 (12), 20742084.

[13] Radojevic, M., Bashkin, V.N., 1999. Practical Environmental Analysis. The Royal Society of Chemistry, Cambridge United Kingdom.

[14] Dwivedi, S.K., Dev, S., 2002. Archives of Environmental Health. 57, 299. 